\title{
Effect of freezing rate on acrosome and chromatin integrity in ram semen* $^{*}$
}

\author{
Zekariya NUR ${ }^{1}$, Berrin ZIK $^{2}$, Burcu USTUNER ${ }^{1}$, Serife TUTUNCU ${ }^{2}$, Hakan SAGIRKAYA ${ }^{1}$, \\ Cansel G. OZGUDEN ${ }^{2}$, Ulgen GUNAY ${ }^{1}$, Ibrahim DOGAN ${ }^{1}$ \\ ${ }^{1}$ Uludag University, Veterinary Faculty, Department of Reproduction and Artificial Insemination, ${ }^{2}$ Department of Histology and \\ Embryology 16059 Gorukle/Bursa Turkey.
}

Summary: The objective of the present study was to investigate the effect of different freezing rates on post-thaw sperm motility, acrosome defect, and sperm chromatin structure and apoptotic activity in ram semen. Collected semen was diluted at 1:5 (semen/extender) with Bioxel ${ }^{\circledR}$ (IMV technologies France) at $30^{\circ} \mathrm{C}$ and then cooled to $5^{\circ} \mathrm{C}$ within $1 \mathrm{~h}$. Cooled semen was subjected to the equilibration for 2 hours. Equilibrated semen was frozen in $0.25 \mathrm{ml}$ straw at two different cooling rates (slow: $0.5^{\circ} \mathrm{C} / \mathrm{min}$ from 5 to $-20^{\circ} \mathrm{C}$ and fast: $5^{\circ} \mathrm{C} / \mathrm{min}$ from 5 to $-20^{\circ} \mathrm{C}$ ). Both groups were frozen from -20 to $-120^{\circ} \mathrm{C}$ at $25^{\circ} \mathrm{C} / \mathrm{min}$ and stored in liquid nitrogen until use. Post-thaw $\left(37^{\circ} \mathrm{C} / 30 \mathrm{~min}\right)$ sperm motility, defected acrosome (Pisum sativum agglutinin fluorescein conjugate, FITC PSA), sperm chromatin structure determined by Acridin Orange (AO) and apoptotic activity using terminal deoxynucleotidyl transferasemediated dUTP nick-end labeling (TUNEL) were evaluated. Post-thaw sperm motility, acrosome defect, AO and TUNEL for slow frozen semen were $42.8 \pm 8.8 \%, 31.6 \pm 12.9 \%, 2.9 \pm 2.4 \%$ and $2.8 \pm 1.6 \%$, and for fast frozen semen were $36.5 \pm 9.9 \%, 24.7 \pm 11.1 \%$, $3.3 \pm 2.2 \%$ and $6.3 \pm 3.4 \%$, respectively. Post-thaw semen analyses showed that there was no significant difference between two freezing curves in terms of acrosome defect, sperm chromatin damage (AO). However, a significant difference was found for postthaw semen motility between two groups $(\mathrm{P}<0.05)$. In conclusion, while the slow freezing procedure improved post-thaw sperm motility, acrosome and chromatin integrities and apoptotic index in ram spermatozoa did not show any significant difference between freezing rates.

Key words: Apoptosis, freezing rate, ram semen.

\section{Koç spermasında dondurma hızının akrozom ve kromatin bütünlüğü üzerine etkisi}

Özet: Bu çalışma, farklı dondurma hızlarının, eritme sonrası motilite, akrozom bütünlüğü, kromatin yapısı ve apoptozis üzerine olan etkilerini araştırmak amacıyla gerçekleştirildi. Toplanan sperma örnekleri $30^{\circ} \mathrm{C}$ 'de $1 / 5$ oranında (sperma/sulandırıcı) Bioxel ${ }^{\circledR}$ (IMV, Fransa) ile sulandırıld 1 ve 1 saatte $+5^{\circ} \mathrm{C}^{\prime}$ ye düşürülerek 2 saat süre ile ekilibrasyona bırakıldı. Ekilibre edilen sperma $0.25 \mathrm{ml}$ 'lik payetlere çekilerek iki farklı soğutma hızında (yavaş: $+5^{\circ} \mathrm{C}$ 'tan $-20^{\circ} \mathrm{C}$ 'a $0.5^{\circ} \mathrm{C} /$ dak ve hızlı: $+5^{\circ} \mathrm{C}$ 'tan $-20^{\circ} \mathrm{C}$ 'a $5^{\circ} \mathrm{C} /$ dak) donduruldu. Her iki grup $-20^{\circ} \mathrm{C}$ 'tan $-120^{\circ} \mathrm{C}$ 'a $25^{\circ} \mathrm{C} /$ dak hizla donduruldu. Eritme sonrasi $\left(37^{\circ} \mathrm{C} / 30\right.$ dak) aşamada; akrozom bozukluğu Pisum sativum agglutinin fluorescein conjugate ( FITC PSA) ile kromatin yapısı Acridin Orange (AO) ile ve apoptozis ise terminal deoxynucleotidyl transferase-mediated dUTP nick-end labeling tekniği (TUNEL) kullanarak belirlendi. Motilite muayeneleri 1sıtma tablalı faz kontrast mikroskop ile gerçekleştirildi. Eritme sonrası motilite, akrozom bozukluğu, AO ve TUNEL değerleri sırasıyla yavaş dondurma için $\% 42.8 \pm 8.8, \% 31.6 \pm 12.9, \% 2.9 \pm 2.4$ ve $2.8 \pm 1.6$ hızlı dondurma için ise \%36.5 99.9 , $\% 24.7 \pm 11.1, \% 3.3 \pm 2.2$ ve $\% 6.3 \pm 3.4$ olarak saptand1. Spermanın eritme sonrası bulgularının değerlendirilmesinde akrozom bozukluğu ve sperma kromatin yapısı (AO) yönünden iki soğutma hızı arasında fark bulunmazken, eritme sonrası motilitede gruplar arasında istatistiksel fark bulundu $(\mathrm{P}<0.05)$. Sonuç olarak, koç spermasında yavaş soğutma prosedürü ile dondurma, eritme sonrası motiliteyi iyileştirirken, akrozom ve kromatin bütünlüğünü ve apoptotik indeksi soğutma oranları arasında önemli bir fark göstermemiştir.

Anahtar sözcükler: Apoptozis, dondurma hızı, koç sperması

\section{Introduction}

The cryopreservation process of mammalian semen results in lower motility and morphological integrity and higher non-return rate when it was compared with fresh semen $(1,2,8,16,26)$. Cooling and freezing rates $(7,15$,
$18,22,25)$, type $(5,16,25)$ and concentration $(7,25,27)$ of cryoprotective agents $(5,16,25)$, dilution rates $(15$, $18,20)$, temperature at which glycerol is added to the semen, equilibration period, and thawing rate interact with the success of post-thaw recovery of spermatozoa

\footnotetext{
* This work was funded by TUBITTAK (TOVAG 105O649)
} 
$(1,2,7,19)$ and fertilizing capability $(19,26)$. Some authors explain these phenomena with reducing transport ability and survival of ram spermatozoa in the female reproductive tract and loss of viability, morphological and DNA integrity during freezing and thawing procedures $(7,16,26)$.

Several researchers have developed different extenders and protocols for freezing ram semen, but the fertility results are not comparable to those obtained with fresh semen and natural mating $(7,18,22,25)$. Thermal shock, formation of ice crystals, dehydration, increased salt concentration and osmotic shock that occur during freeze-thawing have detrimental effects on spermatozoa (22).

The success of cryopreservation of cells is affected by the rate of freezing $(10,11)$ and the composition of the solution where the cells are frozen $(11,16)$. When the cells are rapidly cooled, water is not lost fast enough to maintain the equilibrium; the cells become increasingly supercooled and freeze intracellulary, and this process might affect the integrity of chromatin and the morphology of spermatozoa (11).

Sperm DNA damage may occur during spermiogenesis, spermatogenesis, and transport in the female genital tract or during processing (dilution, cooling, freezing and thawing) for freezing by oxidative stress factors that mainly result from reactive oxygen species (ROS) (6). There are several articles in the literature dealing with the effects of freezing rates on post-thaw motility (3), acrosome integrity (21) and fertilizing ability (3) of ram semen. To our knowledge, in the previous studies, there was no direct evaluation of different freezing rates on the chromatin and apoptotic index of ram semen.

Therefore, the aim of the present study was to compare the effect of freezing rates of ram semen on post-thaw sperm motility, acrosome integrity, and sperm chromatin structure index and apoptotic index.

\section{Materials and methods}

Chemicals: $\quad$ Tris(hydroxymethyl)aminomethane (THAM), Dextran B (150000-200000), glycerol, 1,2 propanediol, sucrose, trehalose, Acridine Orange (AO), Phosphate buffer solution (PBS) tablets, and poly-- ${ }^{-}$ lysine were purchased from Sigma (Sigma Chemical Co., St. Louis, MO, USA). Triton X-100 (10\% stock solution) (11332481001) and In Situ Cell Death Detection Kit were purchased from Roche (Roche Diagnostics GmbH, Mannheim, Germany). Proteinase K (003011) and antibody diluents were purchased from Zymed (Zymed, San Francisco, California, USA). All other chemicals were purchased from Merck (Merck \& Co., Inc., Darmstadt, Germany).
Semen Collection and Cryopreservation: Ten Awassi rams, 3-5 years of age, maintained in Uludag University, Faculty of Veterinary Medicine in Bursa, Turkey, were used during the breeding season. Semen was collected by electrically stimulated ejaculation (Ruakura Ram Probe Plastic Products, Hamilton, New Zealand, probe length $12 \mathrm{~cm}$, diameter $2.5 \mathrm{~cm}, 12 \mathrm{~V}$ ) five times with a one-day inter-semen collection interval (21, 23). To collect semen, rams were restrained physically and lubricated probe was inserted into the rectum with downward pressure on the front of the probe so the electrodes remained nearby the upper portion of the ampullary region. The electrical stimulation was applied for 4-8 s. While the electrostimulation was stopped briefly (3-4 s), further massage was applied with the probe. This cycle was repeated until 1-2 $\mathrm{ml}$ semen was collected (usually 3-4 electrostimulations). Collected semen was placed in a warm water bath $\left(30^{\circ} \mathrm{C}\right)$ and evaluated immediately for consistency, wave motion $(0$ 5 scale) and percentage of motile spermatozoa (0-100\%) (20). Ejaculates with a thick consistency, rapid wave motion (2-5 on a $0-5$ scale) and $>70 \%$ initial motility were used for freezing. Collected semen were diluted at 1:5 (semen/extender) with Bioxel ${ }^{\circledR}$ (IMV technologies, FRANCE) at $30^{\circ} \mathrm{C}$ and then cooled to $5^{\circ} \mathrm{C}$ within $1 \mathrm{~h}$ and equilibrated for $2 \mathrm{~h}$. The equilibrated semen samples were placed into $0.25 \mathrm{ml}$ straws and the straws from each ram were randomly allocated to one of the two freezing rates (3) slow: $0.5^{\circ} \mathrm{C} / \mathrm{min}$ from $5^{\circ} \mathrm{C}$ to -20 and fast: $5^{\circ} \mathrm{C} / \mathrm{min}$ from $5^{\circ} \mathrm{C}$ to -20 . Cooling from -20 to $-120^{\circ} \mathrm{C}$ was at $25^{\circ} \mathrm{C} / \mathrm{min}$. A programmable freezer, Nicool Plus PC freezing machine (Air Liquide, Marne-la-Vallée Cedex 3, France) that had been pre-cooled to $5^{\circ} \mathrm{C}$ was used. Once straws reached $-120^{\circ} \mathrm{C}$, they were then plunged into liquid nitrogen at $-196^{\circ} \mathrm{C}$. At least three straws from each group of frozen ejaculates were thawed in a water bath at $37^{\circ} \mathrm{C}$ for $30 \mathrm{~s}$ to evaluate post-thaw semen characteristics.

Semen evaluation: All semen parameters were assessed after dilution with extender and after thawing. All of the samples were frozen by the same person, and each of the studied semen parameters was measured by the same person on each occasion throughout the study. Sperm motility was assessed subjectively using a phasecontrast microscope $(400 \mathrm{x})$ with a heated stage $\left(38^{\circ} \mathrm{C}\right)$ (21).

Fluorescein lectin staining assay (FITC-conjugated Pisum sativum agglutinin (FITC PSA)): Acrosome integrity was assessed using FITC PSA (12). Briefly, 20 $\mu l$ of diluted semen was re-suspended in $500 \mu \mathrm{l}$ PBS and centrifuged at $2000 \mathrm{rpm}$ for $20 \mathrm{~min}$; the supernatant was then discarded. The spermatozoa pellet was resuspended in $250 \mu \mathrm{l}$ PBS. One drop of resuspended spermatozoa 
was smeared on a glass microscope slide and air dried. Air-dried slides were fixed with acetone at $4^{\circ} \mathrm{C}$ for 10 min, and the slides were covered with FITC PSA solution $(50 \mu \mathrm{g} / \mathrm{ml}$ in PBS solution) in the dark for 30 min. Stained slides were rinsed with PBS solution, covered with glycerol and examined under a fluorescence microscope. At least 100 spermatozoa per smear were evaluated for acrosome integrity.

Acridine-Orange Staining Assay: Sperm DNA integrity was assessed using the AO fluorescence method (11). Air-dried slides were fixed overnight in freshly prepared Carney's solution (three parts of methanol and one part of glacial acetic acid) and allowed to air dry for a few minutes. Dried slides were stained for $3 \mathrm{~min}$ with $0.1 \%$ AO. The stained slides were evaluated immediately under a fluorescence microscope. Normal DNA content showed green fluorescence over the head region, while DNA abnormalities showed varying fluorescence from yellow-green to red. At least 100 spermatozoa per smear were evaluated for DNA abnormalities (11). Sperm cells with changes in fluorescence from yellow-green to red were recorded as sperm with abnormal DNA content.

TUNEL Assay: For the TUNEL technique, we used the In Situ Cell Death Detection Kit with fluorescein (Roche Diagnostics GmbH, Mannheim, Germany) according to the manufacturer's protocol with slight modifications. In brief, one drop of resuspended spermatozoa was smeared on a glass slide and fixed with $10 \%$ formaldehyde for $20 \mathrm{~min}$ at room temperature. The slides were washed in PBS and stored at $4^{\circ} \mathrm{C}$. Upon removal from storage, samples were washed again in PBS (three times for $5 \mathrm{~min}$ each). They were then treated in a humidified chamber with proteinase $\mathrm{K}$ for $10 \mathrm{~min}$ at room temperature, washed with $\mathrm{PBS}$, treated with $3 \%$ Hydrogen peroxide $\left(\mathrm{H}_{2} \mathrm{O}_{2}\right)$ in distilled water for $10 \mathrm{~min}$ at room temperature and washed again with PBS. The slides were permeabilized with $0.1 \%$ Triton $\mathrm{X}-100$ for 5 min on ice.

The permeabilized slides were incubated in the dark at $37^{\circ} \mathrm{C}$ for $1 \mathrm{~h}$ with the TUNEL reaction mixture, which contained terminal deoxynucleotidyl transferase (TdT) plus dUTP label. After labeling, samples were washed with PBS and immediately analyzed using fluorescence microscopy. Negative (omitting TdT from the reaction mixture) and positive (using DNase I, $1 \mathrm{mg} / \mathrm{ml}$, for 10 min at room temperature) controls were included in each trial. At least 100 sperm cells were evaluated to determine the percentage of TUNEL-positive sperm. Each microscopic field was evaluated first under fluorescence microscopy (40X magnification) to determine the number of reactive sperm and then under phase-contrast microscopy to determine the total number of sperm per field.
Statistical analyses: Data were subjected to a statistical analysis with paired samples $\mathrm{T}$ test (SPSS 10.0 ), and $\mathrm{P}<0.05$ was considered as significant.

\section{Results}

Obtained data from each ram were individually analyzed. There were no differences among rams for fresh and post-thaw semen parameters (data not shown). Therefore, obtained semen parameters were pooled and reanalyzed. The mean fresh semen motility and acrosome defect were 73.8 , and 5.7\%, respectively. Post-thaw semen parameters were summarized in Table 1. Postthaw semen motility, for slow and fast frozen semen were $42.8 \%$ and $36.5 \%$, respectively $(\mathrm{P}<0.05)$. FITC PSA was only bound to the acrosomal region of the ram spermatozoa (Figure I). Post-thaw defected acrosome, for slow and fast frozen semen were $31.6 \%$ and $24.7 \%$, respectively $(\mathrm{P}>0.05)$.

Table 1. The effect of freezing rates on post-thaw semen motility, acrosome and DNA integrity, and apoptotic index

Tablo 1. Dondurma hızının eritme sonrası spermatozoa motilitesi, akrozom ve DNA bütünlüğü, ve apoptotik indeks üzerine etkisi

\begin{tabular}{ccccc}
\hline $\begin{array}{c}\text { Freezing } \\
\text { rates }\end{array}$ & Motility & $\begin{array}{c}\text { Damaged } \\
\text { acrosome }\end{array}$ & $\begin{array}{c}\text { Chromatin } \\
\text { index }\end{array}$ & $\begin{array}{c}\text { Apoptotic } \\
\text { index }\end{array}$ \\
\hline Slow & $42.8 \pm 8.8^{\mathrm{a}}$ & $31.6 \pm 12.9^{\mathrm{a}}$ & $2.9 \pm 2.4^{\mathrm{a}}$ & $2.8 \pm 1.6^{\mathrm{a}}$ \\
Fast & $36.5 \pm 9.9^{\mathrm{b}}$ & $24.7 \pm 11.1^{\mathrm{a}}$ & $3.3 \pm 2.2^{\mathrm{a}}$ & $6.3 \pm 3.4^{\mathrm{a}}$ \\
\hline
\end{tabular}

a,b Values with different superscripts in the same colon for different freezing rates are different $(\mathrm{P}<0.05)$.

FITC PSA: FITC-conjugated Pisum Sativum Agglutinin, AO: Acridine Orange

As shown in Figure I (Raw 2), intact DNA of ram spermatozoa showed green fluorescence but the damaged DNA displayed a color spectrum varying from yelloworange to red. Post-thaw sperm chromatin index (AO staining) for slow and fast frozen semen were $2.9 \%$ and $3.3 \%$, respectively $(\mathrm{P}>0.05)$.

The TUNEL assay showed that spermatozoa with DNA fragmentation exhibited green fluorescence (Figure I, Raw 3) and undamaged spermatozoa did not show any fluorescence. Post-thaw ram spermatozoa with DNA fragmentation for slow and fast frozen semen were $2.8 \%$ and $6.3 \%$, respectively $(\mathrm{P}>0.05)$.

The results from post-thaw semen analyses showed that there was no significant difference between two freezing curves in terms of acrosome defect, sperm chromatin damage $(\mathrm{AO})$ and $(\mathrm{TUNEL})(\mathrm{P}>0.05)$ but it existed in post-thaw sperm motility $(\mathrm{P}<0.05)$.

\section{Discussion}

Despite advances in the cryopreservation of bull spermatozoa, there has been lower success with ram spermatozoa (23). Various freezing rates (3), extenders (21) 
1)

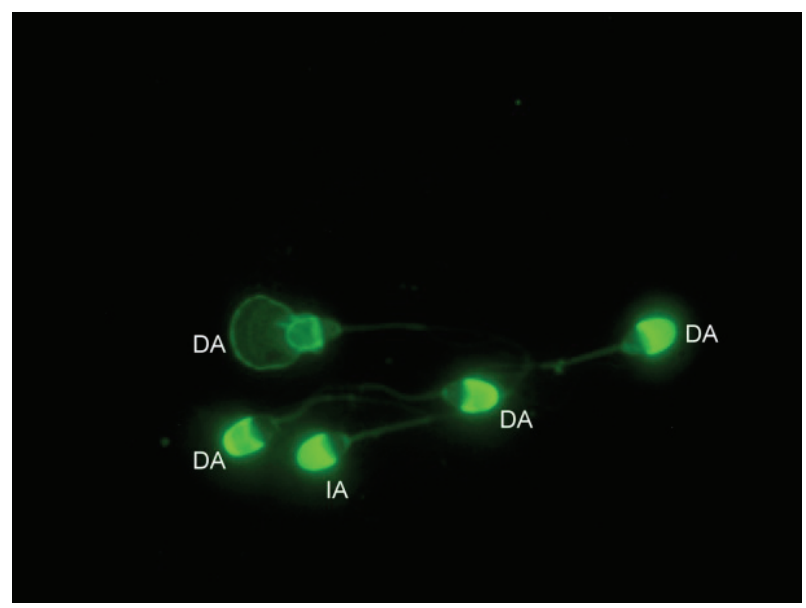

2)
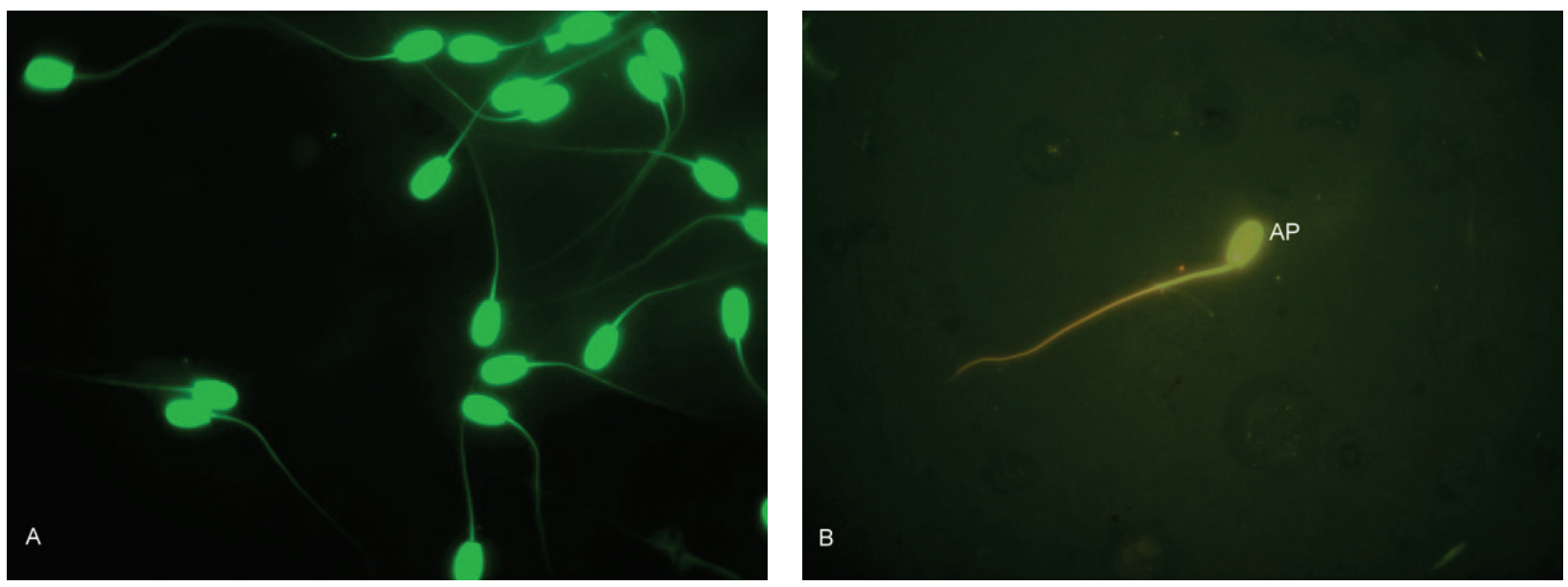

3)
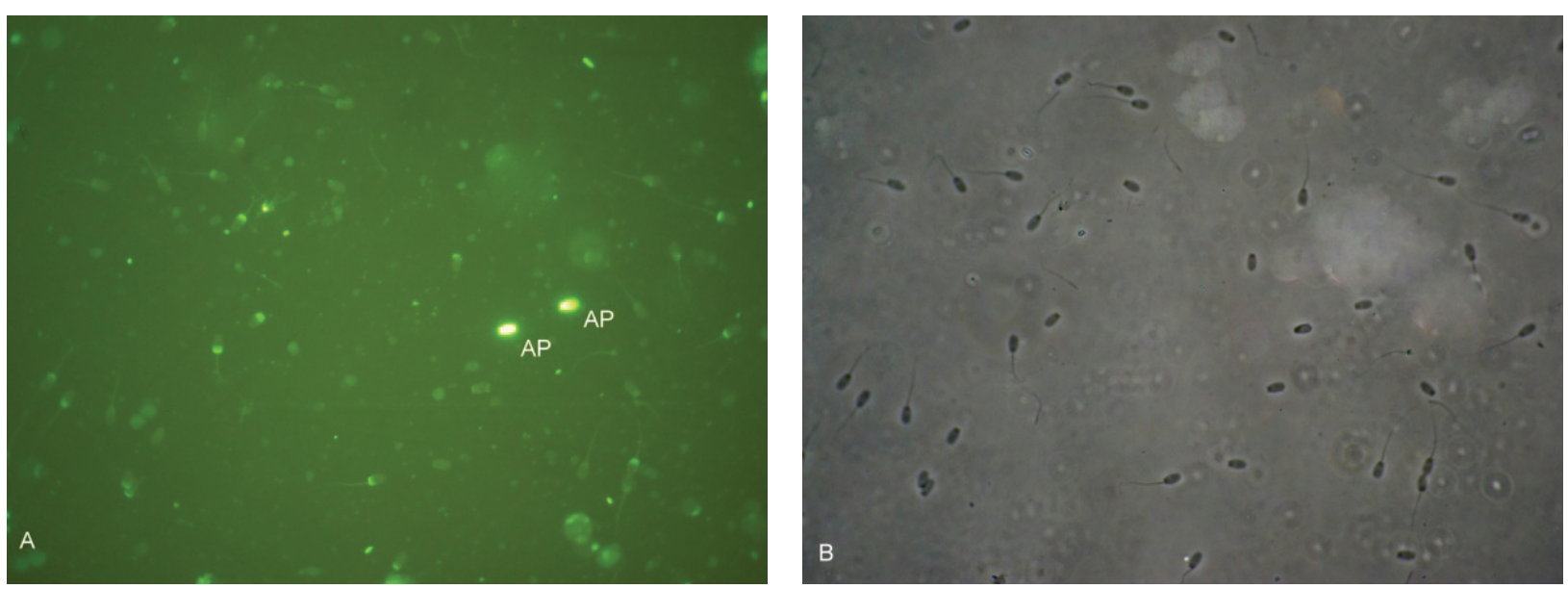

Fig.1.Representative patterns of ram sperm as observed with FITS-PSA, AO and TUNEL staining.

Row 1: FITC-PSA stained spermatozoa with intact and defected acrosome (X40).

Row 2: A: intact, B: fragmented DNA after AO staining (X40).

Row 3: A: Apoptotic spermatozoa under fluorescence microscopy, and B: View under a phase contrast microscopy (X20).

DA: Defected Acrosome, IA: Intact Acrosome, AP: Apoptotic Spermatozoa.

Şekil 1. FITC-PSA, AO ve TUNEL ile boyanan koç spermasının görüntüleri

Satır 1: FITC-PSA ile boyanmış hasar görmüş akrozom (X40)

Satır 2: A: AO boyama sonrası, A: Sağlam, B: Fragmente (kırık) DNA'lı spermatozoon

Satır 3: A: Apoptotik spermatozoonun florosan mikroskoptaki görünümü, B: Aynı görüntünün faz kontrast mikroskoptaki görünümü.

DA: Hasar görmüș akrozom, IA: Sağlam akrozom, AP: Apoptoza uğramıș spermatozoon. 
and cryoprotective agents $(16,21)$ have been described for the cryopreservation of ram semen. Fresh semen motility (73.8\%) and acrosome defect $(5.7 \%)$ were similar to the results of previous studies $(8,16,21)$. It is clear that the cryopreservation and/or thawing process is detrimental to sperm viability (14). Slow dehydration of spermatozoa is associated with higher cell survival, whereas in rapid dehydration rates, cell death is more likely (24). Post-thaw motility of slow frozen semen $(42.8 \%)$ were higher than fast frozen semen $(36.5 \%)$ $(\mathrm{P}<0.05)$. In contrast, O'Neil (17) reported that viability of rapidly frozen semen was better than slow frozen semen.

Freezing and thawing procedures (cooling at $5^{\circ} \mathrm{C}$, dilution, equilibration, and thawing) had negative effects on motility $(\mathrm{P}<0.001)$ and acrosome integrity $(\mathrm{P}<$ 0.001) (16). O'Neil (17) reported that semen frozen rapidly (from $5^{\circ} \mathrm{C}$ to $-25^{\circ} \mathrm{C}$ at $5^{\circ} \mathrm{C} / \mathrm{min}$ ) had significantly better acrosome integrity than semen frozen slowly ($0.05^{\circ} \mathrm{C} / \mathrm{min}$ ) at the same temperature zone. In contrast, Bryne et al. (3) reported that even though the freezing rates had no statistically important effect on post-thaw acrosome defect, defected acrosome rates of fast frozen semen was higher than slow frozen semen. Similarly, the present study showed that freezing rate has no significant influence on post-thaw acrosome integrity.

While no single test accurately predicts fertility of a sperm sample, examining various physical characteristics of semen together provide more reliable results on potential fertility (9). Therefore, the evaluation of apoptotic index of sperm could be useful together with other semen quality assays to assess the potential fertility of a given sample. The freeze-thaw process is detrimental to post-thaw ram semen viability as well as DNA and functional integrity. (16). TUNEL and AO assays revealed that the freezing rates also caused deterioration of DNA integrity. For TUNEL and AO staining, the mean percentage of thawed spermatozoa with chromatin injury was similar in slow frozen semen to fast frozen semen. Hammedeh et al. (11) reported that freezethawing process affected sperm chromatin structure and the mean percentage of human spermatozoa with damaged DNA content were higher in semen frozen on liquid nitrogen vapor than in controlled biological freezer. In the present study post-thaw sperm with chromatin injury in fast and slow frozen samples by TUNEL and AO assay were (6.3\% and 3.3\%) and (2.8\% and $2.9 \%)$, respectively $(\mathrm{P}>0.05)$.

In conclusion, while the result of the present study provide clear evidence that freezing rate influence postthaw semen motility $(\mathrm{P}<0.05)$, the acrosome defect $(\mathrm{P}>0.05)$, sperm chromatin index $(\mathrm{P}>0.05)$ and apoptotic index in ram spermatozoa $(\mathrm{P}>0.05)$ were not influenced.

\section{References}

1. Abdelhakeam AA, Graham EF, Vazquez IA, Chaloner KM (1991): Studies on the absence of glycerol in unfrozen and frozen ram semen. Development of an extender for freezing: effects of osmotic pressure, egg yolk levels, type of sugars and the method of dilution. Cryobiology, 28, 4349.

2. Abdelhakeam AA, Graham EF, Vazquez IA (1991): Studies on the absence of glycerol in unfrozen and frozen ram semen: Fertility trials and the effect of dilution methods on freezing ram semen in the absence of glycerol. Cryobiology, 28, 36-42.

3. Byrne GP, Lonergan P, Wade MJ, Duffy P, Donovan A, Hanrahan JP, Boland MP (2000): Effect of freezing rate of ram spermatozoa on subsequent fertility in vivo and in vitro. Anim Reprod Sci, 62, 265-275.

4. Chohan KR, Griffin JT, Carrell DT (2004): Evaluation of chromatin integrity in human sperm using acridine orange staining with different fixatives and after cryopreservation. Andrologia, 36, 321-326.

5. De Leeuw FE, De Leeuw A M, Den Daas JHG, Colenbrander B, Verkleij AJ (1993): Effects of various cryoprotective agents and membrane-stabilizing compounds on bull sperm membrane integrity after cooling. Cryobiology, 30, 32-44.

6. Duran EH, Morshedi M, Taylor S, Oehninger S (2002): Sperm DNA quality predicts intrauterine insemination outcome - a prospective cohort study. Hum Reprod, 17, 3122-3128.

7. Fiser P, Fairfull RW (1984): The effect of glycerol concentration and cooling velocity on cryosurvival of ram spermatozoa frozen in straws. Cryobiology, 21, 542-551.

8. Gunay U, Dogan I, Nur Z, Manolov I, Sagırkaya H, Soylu MK, Kaptan C, Akpınar L (2006): Influence of bull seminal plasma on post-thaw ram semen parameters and fertility. Bull Vet Inst Pulawy, 50, 503-507.

9. Hafez ESE (1993): Semen evaluation. 405-423. In: Reproduction In Farm Animals. edited by E.S.E. Hafez, Philadelphia, Lea and Febiger.

10. Hammadeh ME, Askari A, Gerorg T, Rosenbaum P, Schmidt W (1999): Effect of freeze-thawing procedure on chromatin stability, morphological alteration and membrane integrity of human spermatozoa in fertile and subfertile men. Int J Androl, 22, 155-162.

11. Hammadeh ME, Dehn CH, Hippach M., Zeginiadou T, Stieber M, Georg T, Rosenbaum P, Schmidt W (2001): Comparison between computerized slow-stage and static liquid nitrogen vapour freezing methods with respect to the deleterious effect on chromatin and morphology of spermatozoa from fertile and subfertile men. Int $\mathrm{J}$ Androl,24, 66-72.

12. Kawakami E, Morita Y, Hori T, Tsutsui T (2002): Lectin-binding characteristics and capacitation of canine epididymal spermatozoa. J Vet Med Sci, 64, 543-49.

13. Li X, Darzynkiewicz Z (1995): Labelling DNA strand breaks with BrdUTP. Detection of apoptosis and cell proliferation. Cell Prolif, 28, 571-579.

14. Martí E, Pérez-Pé R, Muiño-Blanco T, Cebrián-Pérez JA (2006): Comparative study of four different sperm washing methods using apoptotic markers in ram spermatozoa. J Androl, 27, 746-53. 
15. Maxwell WMC, Landers AJ, Evans G (1995): Survival and fertility of ram spermatozoa frozen in pellets, straws and minitubes. Theriogenology, 43, 1201-1210.

16. Nur Z, Zik B, Ustuner B, Sagirkaya H, Ozguden CG (2010): Effects of different cryoprotective agents on ram sperm morphology and DNA integrity. Theriogenology, 73, 1267-1275.

17. O'Neill DJ (1998): Studies on the cryopreservation of ram spermatozoza. MSc(Agr.) Thesis, National University of Ireland.

18. Pontbriand D, Howard JG, Schieve MC, Stuart LD, Wildt DE (1989): Effect of cryoprotective diluent and method of freeze-thawing on survival and acrosomal integrity of ram spermatozoa. Cryobiology, 26, 341-354.

19. Salamon S, Maxwell WMC (1993): Frozen storage of ram semen. II. Causes of low fertility after cervical insemination and methods of improvement. Anim Reprod Sci, 38, 1-36.

20. Sanches-Partida LG, Maxwell WMC, Pateg LG, Setchell BP (1992): Proline and glycine betaine in the cryoprotective diluents for ram spermatozoa. Reprod Fertil Dev, 4, 113-118.

21. Soylu MK, Nur Z, Ustuner B, Dogan I, Sagirkaya H, Gunay U, Ak K (2007): Effects of various cryoprotective agents and extender osmolality on post-thaw ram semen. Bull Vet Inst Pulawy, 51, 241-246.

22. Stanic P, Tandara M, Sonicki Z, Simunic V, Radakovic B, Suchanek E (2000): Comparison of protective media and freezing techniques for cryopreservation of human semen. Eur J Obstet Gynecol Reprod Biol, 91, 65-70.
23. Varisli O, Uguz C, Agca C, Agca Y (2008): Motility and acrosomal integrity comparisons between electroejaculated and epididymal ram sperm after exposure to a range of anisosmotic solutions, cryoprotective agents and low temperatures. Anim Reprod Sci, 110, 256-268.

24. Watson PF (1995) : Recent developments and concepts in the cryopreservation of spermatozoa and the assessment of their post-thawing function. Reprod Fertil Dev, 7, 871-891.

25. Woelders H, Matthijs A, Engel B (1997): Effects of trehalose and sucrose, osmolality of the freezing medium, and cooling rate on viability and intactness of bull sperm after freezing and thawing. Cryobiology, 35, 93-105.

26. Wulster-Radcliffe MC, Wang S, Lewis GS (2004): Transcervical artifcial insemination in sheep: effects of a new transcervical artifcial insemination instrument and traversing the cervix on pregnancy and lambing rates. Theriogenology, 62, 990-1002.

27. Yildiz C, Kaya A, Aksoy M, Tekeli T (2000): Influence of sugar supplementation of the extender on motility, viability and acrosomal integrity of dog spermatozoa during freezing. Theriogenology, 54, 579-585.

Geliş tarihi: 01.07.2010 / Kabul tarihi: 25.01.2011

Address for correspondence:

Dr. Zekariya Nur

Uludag University, Veterinary Faculty, Department of Reproduction and Artificial Insemination 16059 Gorukle/Bursa Turkey. e-mail:nurzek@uludag.edu.tr 